\title{
CAMINHOS E DESCAMINHOS DO MODERNISMO BRASILEIRO: O ‘CONFRONTO’ ENTRE ANITA E TARSILA
}

\author{
Maria de Fátima Morethy Couto \\ Instituto de Artes - UN ICAMP \\ mfmcouto@ iar.unicamp.br
}

\section{Resumo}

Meu texto tem por objetivo analisar um aspecto preciso da historiografia de dois ícones do movimento modernista brasileiro: o "confronto" que teria existido entre a bela Tarsila e a "mulher-menina" Anita Malfatti. Para alguns historiadores, o mal-estar criado pela convivência com Tarsila foi uma das razões que levaram Anita a recuar de seu engajamento vanguardista e buscar uma arte "sem excessos". Destaco aqui a contribuição de dois autores: Gilda de Mello e Souza, em seu artigo "Vanguarda e Nacionalismo na década de Vinte", de 1975, e Sérgio Miceli, em seu livro Nacional Estrangeiro, publicado em 2003, tratam do tema apontando o quanto as vantagens físicas e materiais de Tarsila ajudaram-na a impor-se como a musa final do movimento modernista brasileiro.

Palavras-chave: modernismo brasileiro, crítica de arte, Tarsila do Amaral, Anita Malfatti

Ways and embezzlements of the Brazilian Modernismo: the confrontation between Anita and Tarsila

\begin{abstract}
This text analyses a precise aspect in the history of two icons of the modernist movement in Brazil: the "confrontation" that is supposed to have existed between the beautiful Tarsila and the "woman-girl" Anita Malfatti. To some historians, the unrest caused by Tarsila's company was one of the reasons that took Anita away from her commitment to the vanguard movement and search for an art "without excess". I highlight the contribution of two authors: Gilda de Mello e Souza, in her article "Vanguarda e Nacionalismo na década de Vinte" (Vanguard and Nationalism in the Twentieth Century), of 1975, and Sérgio Miceli, in his book " Nacional Estrangeiro", published in 2003, dealing with the subject and pointing out how Tarsila's advantages, both physical and financial, helped her impose herself as the final muse of the modernist movement in Brazil.
\end{abstract}


Key-words: Brazilian modernism, avant Tarsila do Amaral, Anita Malfatti

\section{DUAS MULHERES ARTISTAS}

O movimento modernista brasileiro foi inegavalmente marcado pelo trabalho de duas mulheres de origem social e temperamento bastante distintos: Anita Malfatti (1889-1964) e Tarsila do Amaral (1886-1973). Enquanto a primeira é tida como 'o estopim do modernismo' no país, devido ao escândalo provocado no acanhado meio paulistano por sua exposição individual de 1917 e pela célebre polêmica criada pelo artigo "Paranóia ou Mistificação", de autoria de Monteiro Lobato, a segunda é considerada a grande musa do movimento, em razão de várias de suas telas tão bem ilustrarem o ideário moderno dos manifestos PauBrasil e Antropofágico.

Trata-se, além disso, de dois entre os maiores nomes da arte brasileira, que lograram escapar da categoria de 'amadoras', recorrentemente utilizada por críticos em atividade no final do século XIX e início do século XX para se referirem ao trabalho de mulheres artistas, e conquistar uma posição de destaque em nossa historiografia. Como observa Ana Paula Simioni,

Seu caso [o de Anita Malfatti] contrasta com o de dezenas de mulheres que expuseram suas obras nos salões oficiais ao longo do século XIX e XX e durante as primeiras décadas do século XX. Tais artistas parecem jamais ter existido, não possuem e não pertencem à história: seus nomes e trajetórias são desconhecidos: suas obras são ignoradas e apenas muito esporadicamente encontram-se presentes em exposições e em acervos de museus, os estudos sobre elas são exíguos. ${ }^{1}$

Donas de um talento rapidamente reconhecido como 'forte e original', que violava os padrões estabelecidos da chamada 'produção feminina' - "obra de moças prendadas que se dedicam à pintura por passatempo ou para aplicá-la às almofadas de seda e aos vasos de barro" 2 - Anita, primeiramente, e Tarsila, em seguida, atraíram para si a atenção e o apoio de um grupo de críticos e homens de letras que lançou as bases do debate em torno da arte moderna no Brasil. Ao relembrar as origens do movimento que eclodiu em São Paulo a partir da realização da Semana de Arte Moderna, Mário de Andrade, em conferência pronunciada em 1942, ressalta o papel de destaque desempenhado pelas obras de Anita Malfatti: 


\begin{abstract}
A Semana marca uma data, isso é inegável. Mas o certo é que a pre-consciência primeiro e em seguida a convicção de uma arte nova, de um espírito novo, desde pelo menos seis anos viera se definindo no sentimento de um grupinho de intelectuais paulistas. (...) Parece absurdo, mas aqueles quadros [da exposição de 1917 de Anita Malfatti] foram a revelação. E ilhados na enchente de escândalo que tomara a cidade, nós, três ou quatro, delirávamos de êxtase diante de quadros que se chamavam $O$ homem amarelo, a Estudante Russa, a Mulher de cabelos verdes. ${ }^{3}$
\end{abstract}

Nesse mesmo texto, Mário cita também o Salão de Tarsila, "o mais gostoso [e o último em data] dos nossos salões aristocráticos" e evoca "o encanto das reuniões que fazíamos antes, quatro ou cinco artistas, no antigo ateliê da admirável pintora". Ele se refere aqui ao chamado 'grupo dos cinco', denominação utilizada informalmente para invocar os inseparáveis amigos modernistas, congregados após a Semana: Mário, Oswald de Andrade, Menotti del Picchia, Anita e Tarsila.

Já Oswald de Andrade, em conferência sobre os aspectos estéticos e sociais do modernismo internacional, proferida em 1944, exalta a contribuição de Tarsila para a renovação da arte brasileira:

Se me perguntassem qual o filão original com que o Brasil contribui para este novo Renascimento que indica a renovação da própria vida, eu apontaria a arte de Tarsila. Ela criou a pintura Pau-Brasil. Se nós, modernistas de 22, anunciamos uma poesia de exportação, ela foi quem ilustrou essa fase de apresentação de materiais, plasticizida por Di Cavalcanti, mestre de Portinari. Foi ela quem deu, afinal, as primeiras medidas de nosso sonho bárbaro na Antropofagia de suas telas da segunda fase, A Negra, Abaporu, e no gigantismo com que hoje renova seu esplêndido apogeu. De outro lado, temos a majestade que atinge o sentido do afresco nos quadros de Lasar Segall. ${ }^{4}$

Cabe, porém ressaltar que somente Oswald saiu em defesa da jovem Anita Malfatti após a crítica negativa de Lobato, em artigo publicado em janeiro de 1918, no qual solicitava "aplausos a quem se arroja a expor no nosso pequeno mundo da arte pintura tão pessoal ou moderna" e afirmava que a "distinta artista conseguiu, para o meio, um bom proveito, agitou-o, tirou-o da sua tradicional lerdeza de comentários e a nós deu uma das mais profundas impressões de boa arte". ${ }^{5}$ Embora Mário de Andrade tenha visitado assiduamente a exposição de 1917 e manifestado seu interesse em comprar o quadro $O$ homem amarelo, ele não se pronunciou na imprensa nessa ocasião. ${ }^{6}$ Aos poucos, porém, Mário torna- 
se amigo de Anita e busca atuar como sua 'consciência-crítica', passando a cobrar publicamente dela a continuidade de suas experimentações estéticas mais radicais. Em seu primeiro artigo a respeito da pintora, datado de outubro de 1921, o escritor entremeia elogios à sua produção expressionista a críticas à sua tentativa mais recente de "construir obras mais acessíveis ao nosso público" e conclui afirmando ver em Anita "uma das mais fortes expressões da faculdade artística nacional":

Anita Malfatti já é um temperamento desenvolvido. Não é promessa de futuro. É realização. Essa realização condensar-se-á naturalmente com a idade. (...) Não sei no entanto se adquirirá maior profundeza da alcançada em certos quadros já feitos. Certamente, no entanto, a pintora se isentará de certas fraquezas pueris que teve, como, por exemplo, o esforço, no fundo louvável, que fez para construir obras mais acessíveis ao nosso público. Abandonando a sua primeira maneira, na qual realizou uma exposição inesquecível [1917], e os ensinamentos expressionistas que recebera na Alemanha, procurou fazer arte mais de toda gente. Erro gravíssimo. A fraqueza de sua segunda exposição provou-o claramente. ${ }^{7}$ Havia, é certo, 4 ou 5 obras muito boas, mas tinha-se a impressão dum artista que tivesse perdido a sua própria alma. Mas a senhorinha Malfatti muito bem compreendeu o seu engano, de novo voltando para dentro de sua personalidade, em tão má hora abandonada. Os seus últimos trabalhos, a estranha e masculina liberdade dos seus novos esboços provam que não perdeu, ao contato de teorias impressionistas que não são as suas, os seus meios de expressão e a prodigiosa fantasia. (...) Deixo-lhe daqui a afirmativa desassombrada do meu grandíssimo entusiasmo; e também minha admiração pela calma firmeza com que entre incréus e indiferentes, vai construindo na sua obra um exemplo que infelizmente não é para nossos dias. ${ }^{8}$

Quando da realização da Semana de Arte Moderna, em 1922, Anita Malfatti, portanto, já era um nome conhecido do meio paulistano de vanguarda e possuía fiéis admiradores entre os primeiros modernistas, com os quais passara a se encontrar com mais freqüência após 1920. Se, como observou Mário de Andrade no texto citado e em diferentes ocasiões posteriores, Anita "fraquejou uns pares de de anos (..) ao ver sua obra modernista repudiada com insulto - quis voltar para trás e quase se perdeu -", às vésperas da Semana ela já havia realizado três exposições individuais na cidade de São Paulo (em 1914, 1917 e 1920) e uma em Santos (em 1921) e participado de três edições do Salão Nacional de Belas Artes. 
Anita e Tarsila

Por ocasião da individual de 1920, no Clube Comercial, Anita recebe o apoio declarado de outro modernista, Menotti del Pichia, o qual não visitara sua mostra anterior:

Caí, a respeito de Anita Malfatti, no visgo de seu estilo [de Monteiro Lobato] e, preso por ele, julguei (...), sem ver todas as obras da artista, toda a obra dela. Comigo, milhares de paulistas, aprioristicamente, assim julgaram essa mulher singular que, quando não tivesse outro mérito, teria o de haver rompido, com audácia de arte independente e nova, a nossa sonolência de retardatários e paralíticos da pintura. (...) Quando defrontei as telas de Anita [da exposição de 1920], comecei a matutar se a acidez de Lobato era justa, e acabei achando-o cruel e exagerado na formidável catilinária que pespegou na nossa brilhante patrícia. Pensei que seria injusto não colocar uma voz de defesa ao lado dessa interessante pintora, que, a meu ver, entre as telas que expõe agora, nos mostra algumas que, em qualquer outro centro, consagrariam o nome de um pintor moderno. ${ }^{9}$

Embora tivesse dúvidas quanto aos rumos a dar para seu trabalho, Anita, juntamente com Brecheret, foi seguramente um dos nomes de maior destaque da Semana no campo das artes plásticas, sendo a artista com o maior número de obras em exibição. Ressalte-se que das 20 obras por ela apresentadas, ao menos sete haviam participado da chamada exposição histórica, de 1917. Tarsila, ao contrário, era até então pouco conhecida do meio paulistano de vanguarda. Enquanto a formação de Anita se dera na primeira metade dos anos 1910, quando, custeada pelo tio e padrinho, o engenheiro Jorge Krug, freqüentara escolas e ateliês de arte na Alemanha (1910-1914) e nos Estados Unidos (1915-1916) ${ }^{10}$, Tarsila, ampararada pelo pai, grande fazendeiro de café, empreendeu estudos mais sistemáticos no campo das artes apenas a partir 1916, primeiramente com William Zadig, escultor sueco radicado em São Paulo, e em seguida com o italiano Mantovani, também aqui radicado. Tinha então 30 anos de idade e uma filha de 12 anos. ${ }^{11}$ A partir de 1917, passa a freqüentar o ateliê do pintor acadêmico Pedro Alexandrino, com quem toma aulas de pintura e desenho. Pintava "sem rebeldias", como assinala Aracy Amaral, "com tintas diluídas e suaves", aplicadas de forma a criar uma atmosfera lírica em suas telas. Curiosamente, será nas aulas de Pedro Alexandrino que Anita e Tarsila se conhecerão, no ano de 1919, quando a primeira, segundo sua biógrafa Marta Rossetti Batista, resolve "dar um mergulho na arte acadêmica, procurando conformar-se às exigências do meio". ${ }^{12}$ No início do ano seguinte, ambas freqüentam as sessões de modelo vivo conduzidas pelo pintor alemão Elpons, o qual também seria professor de Di Cavalcanti. 
Em junho de 1920, Tarsila parte para a Europa juntamente com sua filha Dulce, que seguiria seus estudos como interna de um colégio londrino. Decidida a investir em sua formação enquanto pintora, Tarsila fixa-se em Paris e inscreve-se na Academia Julian, freqüentando em seguida o ateliê de Émile Renard, então professor da Escola de Belas-Artes. Durante sua estada, que durará dois anos, manterá contato regular com Anita. Em outubro de 1920, Tarsila escreve à amiga, relatando-lhe suas primeiras impressões do circuito cultural parisiense e encorajando-a a retornar ao velho Continente:

Estou te escrevendo daqui da Academia Julian. Venho todas as manhãs. Estou trabalhando num grande gupo de umas 50 alunas. Está me parecendo que muitos são os chamados mas poucos os eleitos. Não vejo uma aluna forte. (...) Já estive no 'Grand Palais', no salão de Outono: olha, Anita, quase tudo tende para o cubismo ou futurismo. Muita natureza-morta, mas daquelas ousadas em cores gritantes e forma descuidada. Muita paisagem impresionista, outras dadaístas. (...) Depois de ter visto muito esta pintura cheia de imaginação, não suporto mais as coisas baseadas no bom senso e muito ponderadas. (...) Também não estou de acordo com o cubismo exagerado e o futurismo. (...) Estou certa de que as tuas telas teriam perfeitamente aceitação, pois é essa a arte compreendida aqui. As tuas pinturas nunca foram futuristas como queriam dizer os pouco entendidos aí. Não compreenderam o teu talento e nada mais. Trata de arranjar as malas e dize-me em que vapor vens. ${ }^{13}$

Anita, de fato, ansiava retornar à Europa, mas não mais contava com o apoio incondicional do tio. Em 1921, solicita o Pensionato Artístico do Estado de São Paulo, mas será Brecheret o agraciado, tornando-se assim o primeiro modernista a obter esta bolsa. Em setembro de 1921, em carta a Tarsila, Anita menciona sua firme intenção de deixar o Brasil uma vez mais, ressaltando, porém as dificuldades que enfrenta por ser "uma mulher sozinha e sem capital":

Eu só calculo o que você terá armazenado de impressões e quanto não terá apurado o gosto. Acho o meu cego, completamente, só me resta a lembrança de como eu sentia antes de vir para esta sonolência. Tenho muitas lições agora e isto me tira o tempo e a energia, mas estou o tempo todo lutando, mesmo que seja mais espiritualmente que em prática. Continuo firme na idéia de seguir para a Europa na próxima primavera. Só Deus sabe se o conseguirei. (...) Agora uma mulher sozinha, sem capital e com honestidade não pode fazer fortuna, disso já me convenci, por isso me contento em ser uma artista sem popularidade nem dinheiro, no vernáculo piedoso 
dos que me querem bem, 'incompreendida'. (...) Estou voltando às coisas muito modernas, pois são tais coisas que me alegram a alma (...) Tem havido exposições italianas e estas vendem sempre. ${ }^{14}$

Quando do retorno de Tarsila ao Brasil, em junho de 1922, será Anita quem a introduzirá no núcleo modernista. "Tarsila nos conquistou a todos de saída", relembraria. De fato, o impacto por ela causado parece ter sido grande, conforme relata Menotti del Picchia: "foi Anita quem me apresentou a artista [Tarsila], numa confeitaria elegante onde tomávamos chá. (...) - Esta é Tarsila, paulista, pintora e vem de Paris. Pintora? Eu tinha na frente uma das criaturas mais belas, mais harmoniosas e mais elegantes que me fora dado ver..." ${ }^{15}$ Anos mais tarde, em depoimento à Aracy Amaral, ele voltaria a evocar os encantos da artista, afirmando ter sido ele "o único que por ela não se apaixonara, porque todos, todos, todos, ficavam atraídos pela sua presença envolvente, o que causava em Oswald um ciúme terrível a ponto de nos bombardear com bilhetinhos... e eu era o seu confidente". ${ }^{16}$ Inicia-se então um período de freqüentes encontros e trocas do chamado 'grupo dos cinco' no ateliê de Tarsila, na casa de Mário, na garçonnière de Oswald. "Parecíamos uns doidos em disparada por toda a parte na Cadillac de Oswald, numa alegria delirante, à conquista do mundo para renová-lo. Era a Paulicéia desvairada em ação", escreveria Tarsila sobre o grupo em $1950 .{ }^{17}$ Por vezes, as duas artistas pintam o mesmo motivo, como os vasos de margaridas que Mário de Andrade enviara uma ocasião ao ateliê de Tarsila, por vezes retratam a mesma pessoa (Fernanda de Castro, Mário de Andrade). Expõem juntas, em setembro, no I Salão da Sociedade Paulista de Belas-Artes, iniciativa do governo do Estado. A amizade entre ambas, ao que tudo indica, consolida-se. "Anita parece ter sido a companheira de sempre para Tarsila nesta sua estada em São Paulo, ao mesmo tempo que a corte por parte de Oswald se define gradativamente", observa Aracy Amaral..$^{18}$ Ressaltemos que o papel de cada uma estava então bem definido: Anita era um dos ícones do movimento moderno e Tarsila uma artista a ser conquistada. De passagem por São Paulo, o escritor pernambuco Inojosa Martins assim descreve a situação de Tarsila no grupo:

Tarsila do Amaral ainda não estava integrada no credo novo, que os demais professavam com um entusiasmo quase infantil. Com que ânsia espiritual a procuravam convencer! (...) Semelhavam quatro crianças, a quererem conduzir a um bazar de brinquedos a amiga a quem foram visitar. (...) Ouvi-as Tarsila do Amaral, com a sua cabelereira revolta de sonhadora impenitente, com os seus lindos olhos sevilhanos (...) e sorria lisonjeada - um sorriso de aprovação tácita, aprovação silenciosa àqueles cavaleiros andantes do ideal. ${ }^{19}$ 


\section{DUAS BRASILEIRAS EM PARIS}

Em novembro de 1922, Tarsila embarca novamente para Paris, financiada pela família, mas disposta agora a "procurar nova orientação para seus estudos". Seu encontro com os modernistas de São Paulo foi de fato determinante para que ela decidisse dar uma guinada em sua carreira. "Parece mentira... mas foi no Brasil que tomei contato com a arte moderna (...) e, estimulada pelos meus amigos pintei quadros, onde minha exaltação se comprazia na violência do colorido", afirmaria a artista três décadas mais tarde. ${ }^{20}$ Por outro lado, seu envolvimento amoroso com Oswald de Andrade, que logo seguiria para a Europa e a acompanharia em sua estada de um ano na capital francesa, ${ }^{21}$ assim como os encontros e relações sociais e artísticos que ambos travaram em Paris foram fatores igualmente decisivos para que ela estabelecesse as bases de seu novo vocabulário plástico, incorporando preceitos da vanguarda cubista.

Em abril de 1923, Tarsila escreve aos pais informando-lhes estar trabalhando "com um ótimo professor, um desses modernos: M. Lhote. Com duas lições ganhei mais do que em dois anos". ${ }^{22}$ No mês seguinte, pergunta em carta endereçada a Mário de Andrade se ele lera um artigo recém publicado de seu "mestre Gleizes". ${ }^{23}$ Nesse mesmo período, conhece o poeta Blaise Cendrars, o qual os introduziria - a ela e a Oswald - a uma parcela expressiva do mundo artístico e literário parisiense. Por seu intermédio, conhecem Brancusi, Jean Cocteau, Fernand Léger, Erik Satie, os marchands Ambroise Vollard e Léonce Rosenberg. O casal também se liga de amizade com Paulo Prado e Olívia Guedes Penteado, nomes de grande importância para a difusão do movimento modernista em São Paulo. Em setembro, poucos meses antes de retornar ao Brasil, Tarsila decide frequientar por algumas semanas o ateliê de Léger. ${ }^{24}$

Nas freqüentes cartas que envia à família, relata seus progressos no campo das artes, fala de suas intenções profissionais e descreve suas freqüentações mundanas, ressaltando sua posição de destaque em recepções e espetáculos. Ainda em abril, revela ter consciência do lugar que lhe caberia ocupar para tornar-se uma artista de renome, tanto no Brasil como no exterior:

Sinto-me cada vez mais brasileira: quero ser a pintora da minha terra. Como agradeço ter passado na fazenda a minha infância toda. As reminiscências desse tempo vão se tornando preciosas para mim. Quero, na arte, ser a caipirinha de São Bernardo, brincando com bonecas de mato, como no último quadro que estou pintando. Não pensem que essa tendência brasileira na arte é mal vista aqui. Pelo contrário. O que se quer aqui é que cada um traga contribuição de seu próprio país. Assim se explicam o sucesso dos bailados russos, das 
gravuras japonesas e da música negra. Paris está farta de arte parisiense. ${ }^{25}$

Em outubro, ao justificar aos pais sua demora em partir, declara: "ficarei de uma vez livre de mestres. Se eu já tivesse partido, seria obrigada talvez a ficar numa posição subalterna durante anos ainda". ${ }^{26}$ Tarsila busca afirmar-se agora como uma profissional independente, e não como uma aluna dedicada. Seus quadros desse período, como Caipirinha e A Negra ou seu famoso Auto-retrato com casaco vermelho, atestam o salto dado pela artista quando confrontados a qualquer obra de sua autoria realizada antes de 1923, salto este decorrente de sua pronta assimilação dos conselhos dos novos mestres. As formas são agora simplificadas; as figuras, estilizadas e/ou geometrizadas. O traçado é claro, seguro, a pincelada é lisa; os planos são interligados, o que propicia uma maior estruturação e unidade compositivas. As cores são aplicadas cuidadosamente; os campos de cores não se contaminam, não rompem com os limites de cada figura, mas contribuem para a compreensão do volume dos elementos representados.

Ao regressar, Tarsila concede uma entrevista ao jornal Correio da Manhã na qual afirma estar vivendo numa grande época, de um "renascimento formidável de letras e artes", e se define como uma pintora cubista. Em sua opinião, "o cubismo liberta porque tem a vantagem de ser uma escola de invenção. (...) O cubismo é exercício militar. Todo o artista, para ser forte, deve passar por ele". ${ }^{27}$ Anita também retornaria à Europa, em viagem de estudos, em agosto de 1923, após obter o tão almejado Pensionato Artístico do Estado de São Paulo, graças à interferência do amigo Mário de Andrade junto ao senador Freitas Valle, influente figura no mundo das artes em São Paulo. ${ }^{28}$ Podemos avaliar a importância desse apoio no relato emocionado deixado pela artista sobre o momento em que recebeu a notícia da bolsa:

Mário de Andrade lia uma conferência. Ao terminar a leitura, Dr. Freitas Valle num grande gesto levantou-se do trono e encaminhou-se para mim, o que me assustou de tal maneira que perdi o controle... Ele realmente chegou-se para junto de mim e disso mesmo de verdade que eu poderia embarcar para a Europa em viagem de estudos... - qualquer coisa me aconteceu, não sei se voei pelo telhado ou se afundei no chão... então surgiu uma dama, eu não a conhecia, que me reconfortou e rindo-se muito da minha confusão, afirmava ser aquilo verdade... Era Dona Olívia... ${ }^{29}$

Instala-se em Paris, em um pequeno hotel em Montparnasse, e monta, no ano seguinte, um modesto ateliê próximo ao de Brecheret, que ainda usufruía da bolsa conquistada em 1921 e com quem conviveria estreitamente. Diferentemente de Tarsila, que faria diversas idas e vindas entre o Brasil e a França nos anos 
1920, Anita permanecerá na Europa durante os cinco anos de vigência da bolsa, viajando esporadicamente dentro do Velho Continente. Tampouco terá uma vida social intensa ou freqüentará artistas e intelectuais de vanguarda durante sua estada. Residirá durante grande parte de seu estágio em Paris com sua mãe, sua irmã Georgina e uma prima, assumindo "atitude meio retraída, meio isolada", nos dizeres de Marta Rossetti. Ao contrário da amiga, interessa-se agora por pintores de postura mais comedida, como Maurice Denis, que buscam criar uma arte moderna sem grandes excessos. ${ }^{30} \mathrm{Em}$ depoimento dado quando de seu retorno ao Brasil, em 1928, ela declararia que desde 1923 já era perceptível o ocaso das vanguardas européias e o esgotamento de suas experiências revolucionárias:

Em Paris, no ano em que lá cheguei, 1923, encontrei o ambiente que é o mesmo, quase, dos dias de hoje: um movimento generalizado dos artistas, norteados definitivamente por tendências modernistas. Há a notar, entretanto, um pormenor que não pode passar despercebido: os extremistas não têm mais lugar de destaque. As tendências modernas a que me referi representam correntes moderadas, sem, contudo, deixar de ser caracteristicamente novas. ${ }^{31}$

Nesse mesmo depoimento, afirma ter se comportado como uma colegial em seus primeiros anos em Paris. Manteve-se independente dos movimentos em voga, mas procurou "inteirar-se de tudo quanto acontecia ali". Para tanto, "freqüentou as academias de cursos livres, visitou os ateliês, rebuscou nos salões o que se fazia de mais avançado" e, sobretudo, não cessou de "preregrinar pela grande cidade, à procura do que ver, do que aprender. Ver, distinguir...". ${ }^{32} \mathrm{Nessa}$ preregrinação, não contou, porém com o apoio de Tarsila, a qual escrevera aos pais em setembro de 1923:

Acha-se também aqui o Di Cavalcanti, pintor do Rio muito considerado. Ele e Anita disputarão a mim o primeiro lugar na pintura moderna brasileira. Apesar da grande confiança em mim, creio urgente ativar meus estudos. Esperei Anita também para saber como seria recebida aí a exposição que levo. Ela me deu, no nosso primeiro encontro no hotel, a noção de que em vez de uma amiga tenho uma rival. ${ }^{33}$

Rivalidade de fato ou fantasia de quem ansiava por vencer no exterior, a verdade é que as duas artistas pouco se encontrarão nos anos em que residirão na França. Mário de Andrade, fiel correspondente de ambas, tentará reaproximá-las. Em carta a Anita datada de 13 de novembro de 1924, escreveria: "Fiquei muito contente em me falares bem de Tarsila. Acho dum ridículo enorme o frio que separou vocês. Que diabo! Deixem disso. É possível que vocês duas, tão 
diversamente orientadas e de tendências tão opostas, não gostem uma da obra da outra, mas que tem isso a com a amizade?" ${ }^{34}$ Em abril de 1926, pegunta para o casal Tarsila e Oswald, ou "Tarsivaldo", como ele gostava de chamá-los: "Vocês já viram Anita? Que tal o quadro dela que esteve no Salão? Olhem, não se esqueçam de arranjar as coisas para ficarem todos camaradas outra vez, não gosto dessas briguinhas muito não, é tão sossegado a gente andar todos allons enfants de la patrie de braço dado se rindo uns pros outros sem arreganhando os dentes, com perdão da palavra". ${ }^{35}$ Ironia do destino, três anos mais tarde, Mário romperia definitivamente com Oswald de Andrade, ao que tudo indica em função de comentários irônicos e agressivos que esse último escrevera a seu respeito na Revista de Antropofagia, publicada no Diário de São Paulo.

As trajetórias artísticas de Tarsila e Anita também transcorrerão de modo diferenciado, embora seja importante ressaltar que nenhuma das duas alcançou grande fama no circuito das artes parisiense. Sobre esse ponto, observa Aracy Amaral tratar-se, na realidade, de um fenômeno mais amplo, que atingiu todos os pintores brasileiros residentes na Europa durante esse período, aí incluídos os nomes de Di Cavalcanti, Brecheret, Antônio Gomide e Rego Monteiro:

Diferentemente de importantes artistas latino-americanos de geração próxima, como Torres-Garcia, Pettorutti, Rivera e alguns outros argentinos, os brasileiros não chegam a participar, como agentes, do meio parisiense nos anos 20, em mostras coletivas de qualidade ou de movimentos como o surrealista, ocorrido nessa década. Sua presença é discreta, em exposições individuais, em galerias particulares ou em mostras coletivas, como as dos salões oficiais, do Indépendents e dos Surindépendents. ${ }^{36}$

Tarsila, porém, em função de seu entrosamento e convívio com alguns nomes do mundo das artes da capital francesa e sobretudo em função de sua amizade com Blaise Cendrars saberá se fazer notar. Ressalte-se que, em seu caso, não é possível dissociar sua aceitação no restrito meio vanguardista de Paris de suas frequëntações sociais, sem que isso represente nenhum demérito à sua obra. Nela e em Oswald, "a ambição de brilho social se misturava às pretensões de supremacia intelectual, num amálgama de práticas de consumo de luxo e investimentos culturais". ${ }^{37} \mathrm{Se}$, por um lado, Tarsila teria em Oswald um companheiro que se preocuparia com sua projeção, "estimulando seu cuidado no vestir-se, insistindo até por correspondência na forma como ela se apresentava", ${ }^{38}$ por outro ela também se mostraria bastante consciente da impressão que causava à sua volta, conforme expõe em diferentes relatos à família. Em 1923, escrevia aos pais dizendo que esteve "num jantar dos artistas do Salão da Tulherias. Muita gente. Artistas de valor e outros medíocres. Estreei o meu vestido amarelo de 
chez Patou. Parecia uma rainha. Todos os olhares convergiram para mim..." 39 Dois anos mais tarde, em outra de suas temporadas em Paris, relataria:

Ontem fui com Betita a um baile na Ópera. Fiz sucesso como mulher linda e dei um passo importantíssimo na minha carreira artística pois fui convidada pelo sr. Maurice de Valeff, diretor do jornal Paris-Midi e uma das figuras mais importantes da imprensa daqui, para realizar minha exposição no grande salão de festas de Le Journal. ${ }^{40}$

Aqui, os dois papéis - de mulher elegante e de artista em busca de reconhecimento - se mesclam. Todavia, acatando os conselhos de Cendrars, que escreveria ao casal dizendo que o local não era de grande prestígio e que Tarsila deveria produzir outras telas de qualidade equivalente a Morro da Favela antes de decidir-se a expor, ela não aceita o convite mencionado. Na opinião de Cendrars, ela deveria tentar sua sorte enquanto artista na rua La Boétie, centro nobre da cidade - localizada perto do Champs Elysées e do Faubourg Saint-Honoré -, e ponto alto do mercado de arte, sugerindo como possibilidade a galeria Percier, onde de fato Tarsila realizaria suas duas exposições individuais na França, em 1926 e em 1928 - as primeiras individuais de sua carreira. A respeito da importância de Cendrars para o deslanche da carreira de Tarsila, observe-se ainda que em 1924 a pintora ilustrara o livro de poemas de Cendrars, Feuilles de Route I. Le Formose, inspirado em sua viagem do Havre a São Paulo, para onde veio a convite de Paulo Prado e por sugestão de Oswald de Andrade. Juntamente com o poeta francês, alguns dos modernistas brasileiros, entre eles Mário de Andrade, Oswald, Dona Olívia Guedes Penteado, e Tarsila, visitariam nessa ocasião as cidades históricas de Minas Gerais, naquela que seria conhecida como a viagem de (re)descoberta do Brasil.

Cendrars será também o autor do poema que servirá de prefácio para o catálogo da exposição de 1926, exposição essa que reunirá 17 pinturas da artista produzidas entre 1923 e 1926, além de desenhos e aquarelas. A preocupação com a apresentação dos trabalhos se faz evidente na decisão da artista de encomendar a Pierre Legrain, famoso encadernador da época, molduras especiais para suas telas. Esta associação se repetiria na segunda exposição de Tarsila, em 1928. Sobre ela, escreve Aracy Amaral que Tarsila "pagou mais a Pierre Legrain pelas molduras de sua exposição em 1928, 6 mil francos, que o valor, segundo depoimento da própria artista, que ela teria pago pela célebre tela de Robert Delaunay, a Tour Eiffel (1,5 mil francos). ${ }^{41}$ As resenhas publicadas na imprensa local sobre a exposição de 1926 destacaram "o encanto e franqueza dessas imagens do Brasil", "o exotismo da cor e dos motivos", assim como a técnica apurada da artista, que sabia conjugar ingenuidade e inteligência. Vários 
Anita e Tarsila

foram os críticos a associar o trabalho de Tarsila ao de Fernand Léger. Na exposição de 1928 foram apresentadas 12 telas, todas, à exceção de duas, realizadas nesse mesmo ano, como Sapo, Sono, Abaporu. São composições de sua fase "antropofágica", nas quais as referências ao Brasil se fazem menos anedóticas e a atmosfera onírica prevalece.

Anita, por sua vez, apesar de seu renome entre os modernistas brasileiros e de seus dois estágios anteriores no exterior, assumirá para si, como ela própria afirma, uma posição de "colegial", de aprendiz, talvez em função de sua situação de bolsista do governo do Estado. Sua biógrafa, Marta Rossetti Batista, assinala o paradoxo no fato de uma artista "em plena maturidade (...) obter uma bolsa de aperfeiçamento para estudantes de arte, com exigências rígidas, que lhe davam uma orientação essencialmente acadêmica", como, por exemplo, a necessidade do envio de cópias de quadros célebres e de uma composição original, de tema histórico, mitológico ou religioso. ${ }^{42} \mathrm{~A}$ artista, apesar de seu engajamento anterior em prol de uma pintura moderna, cumprirá com todos os compromissos, realizando cópias de obras de Botticelli, Rafael, Delacroix e Millet e uma composição de temática religiosa, Ressureição de Lázaro, hoje no Museu de Arte Sacra de São Paulo. Paralelamente, criará interiores detalhistas, de tons intimistas e contornos delicados, que lembram os quadros de Bonnard e Vuillard, e paisagens de fatura equilibrada, construídas por planos sucessivos, que remetem a Cézanne, como Paisagem dos Pirineus, de 1926. Em suas naturezas-mortas, o uso da cor é mais livre e os contrastes tonais mais acentuados, embora sejam menos exuberantes do que os quadros de 1915/1917. Assim como Tarsila, Anita realizará uma exposição individual em Paris no ano de 1926, na galeria André, situada na rue des Saints-Pères, nas cercanias da Escola de Belas-Artes. Nessa ocasião, apresentou 22 telas, 14 aquarelas e 11 desenhos, em sua grande maioria trabalhos recentes, e logrou obter alguns comentários positivos da imprensa francesa. Todavia, diferentemente de Tarsila, Anita fará envios constantes aos Salões parisienses de maior prestígio, apostando nessa via para obter o reconhecimento desejado para seu trabalho. Em sua estada em Paris, participará das edições do Salão de Outono de 1924 e 1927, do Salão dos Independentes de 1926 e 1927 e do Salão das Tulherias de 1927. Alguns artigos na imprensa, publicados nessas ocasiões, destacaram, em breves comentários, a segurança de sua pincelada e seus dons excepcionais de colorista, outros, porém, assinalaram a falta de unidade de seu trabalho. ${ }^{43} \mathrm{~A}$ artista, ao que tudo indica, parecia satisfeita com os progressos que realizava, escrevendo em abril 1925 para Mário de Andrade:

A fortuna virou para mim. Veja quanta coisa boa. Na minha pintura chegarei a uma grande etapa. Fiz uma descoberta enorme 'para mim'. Sei que agora poderei sempre conseguir a uni- 
ficação harmoniosa dos meus tons e a relação entre eles de modo que pareçam todos partes componentes de um só corpo. Descobrir a cor local e aplicá-la simultaneamente conforme o problema a resolver. (...) Trabalharei agora com método e compreensão e sei que isto marca o começo de uma época. ${ }^{44}$

E não se furtou a tecer críticas à exposição de 1926 de Tarsila ao amigo. Este responde em carta que tem opinião diferente da sua, mas "isso não impede que ache a [dela] perfeitamente plausível e sobretudo dada com muita isenção de ânimo e sinceridade". ${ }^{45}$

\section{A RECEPÇÃO CRÍTICA DE SUAS OBRAS PELOS MODERNISTAS BRASILEIROS}

Os modernistas brasileiros mostrar-se-iam cada vez mais desapontados com o novo estilo de Anita, ao mesmo tempo em que passariam a tecer diversos elogios à produção mais recente de Tarsila. Em pouco tempo alterar-se-iam os papéis de cada uma na ótica dos protagonistas do movimento modernista paulistano. Já em 1923, Sérgio Millet escreve de Paris para Couto de Barros dizendo que "Anita já não é nossa grande artista. É Tarsila". ${ }^{46}$ Ao descrever em detalhes a recepção oferecida nesse mesmo ano pelo embaixador brasileiro Souza Dantas à vanguarda artística e literária francesa, na qual estiveram presentes alguns artistas brasileiros, Millet mostra-se encantado pela "talentosa pintora patrícia [que] hoje dispõe de seguríssima técnica, permitindo-lhe realizar as mais ousadas concepções". ${ }^{47}$ Millet, além disso, provalvemente teceu comentários negativos sobre Anita em carta a Mário de Andrade, pois este lhe responde, em correspondência datada de 11 de agosto de 1924: "E Anita? O que todos vocês me dizem sobre ela me horroriza". Acho que vocês são um pouco injustos com Anita. Ela me mandou um desenho excelente e os croquis de várias composições novas. Excelentemente bem construídos". ${ }^{48}$ Anita, por sua vez, queixa-se a Mário, em 1925, de seu isolamento em Paris, revelando que percebia que seus interesses se distanciavam em vários aspectos daqueles dos modernistas que se encontravam na França. Ao que o amigo lhe responde, sem contar toda a verdade:

Os meus amigos me conhecem bem e nunca me falaram mal de você ou de suas obras, porém eu senti que se estavam desinteressando por você. Senti e sofri. Acho que eles procedem mal (...) porque si você mudou de orientação, si você não tem a opinião mesminha deles, isso não é razão para que se afastem. (...) Se um dia eles reconheceram que você tinha talento, deviam esperar pra ver o que você ia fazer no novo caminho. ${ }^{49}$ 
Anita e Tarsila

Entretanto, o próprio Mário não tardaria a concordar com seus colegas e a expressar, velada ou abertamente, suas críticas. Suas cartas a Anita e a Tarsila, hoje publicadas, revelam seu carinho por ambas as artistas mas também sua decepção com os rumos tomados por Anita e sua fascinação crescente pela figura e pelo trabalho de Tarsila. De sua parte, ele claramente ansiava por experimentações mais ousadas da primeira, na trilha de seus quadros "expressionistas", realizados quando de seus dois estágios iniciais no exterior. Em diversas ocasiões, ele tocaria nesse assunto com a artista, sem maiores sutilezas. Em outubro de 1924, por exemplo, recomendaria à amiga Anita:

Continua assim a trabalhar, estudar, criar e fazer coisas grandes. Sabes que, além da nossa amizade que não morre e que perduraria mesmo que um de nós decaísse, eu conservo inalterável confiança em ti. Conheço e provei durante o nosso longo convívio aqui o teu talento. Tenho a certeza que ainda darás ao Brasil algumas obras iguais ou mesmo superiores talvez ao Japonês e ao Homem Amarelo. Sei disso e espero com confiança e entusiasmo. ${ }^{50}$

Meses antes, ele havia lhe relatado seu entusiamo com as novas obras de Tarsila, dizendo: "Quem me surpreendeu inteiramente foi Tarsila. Que progresso, para tão pouco tempo! (...) Estou entusiasmado. (...) Aquela Tarsila curiosa de coisas novas, mas indecisa, insapiente que eu conhecera, desapareceu. Encontrei uma instrução desenvolvida, arregimentada e rica. Vê-se que muito ouviu, muito leu e muito pensou". ${ }^{51}$

Em algumas de suas cartas a Anita, a comparação entre ambas é feita sem rodeios, como em dezembro de 1925:

Tarsila está um bicho. Tem feito coisas colossais, tentando a criação duma arte brasileira mas brasileira de verdade. Certas paisagens das últimas e uns quadros aproveitandos tipos e santos nacionais são das milhores pinturas modernas que conheço. Junto a um dinamismo e sobretudo uma firmeza de linha e um equilíbrio perfeitos, um gosto forte de coisa bem brasileira com cheiro de manacá e abacaxi, melando a alma da gente. Acho que ela achou com felicidade rara o caminho que devia seguir. ${ }^{52}$

Algumas linhas adiante, ele complementa, de forma mais comedida:

Diante disso inda mais me desperta a vontade de conhecer os quadros de você, sei que você também se meteu num problema intricado, resolver definitivamente a sua orientação pessoal. Tenho confiança em você pra saber desde já que você há de chegar a uma solução satisfatória. ${ }^{53}$ 
Ressalte-se, além disso, que em suas cartas endereçadas a Tarsila, Mário emprega um tom que jamais utilizaria para Anita, chamando-a de "Tarsila boniteza", ou mesmo comparando-a com a deusa greco-romana Nêmesis - que cuidava da boa sorte na vida humana e que aplicava castigos devido a más ações -, para logo se "corrigir": "Que és deusa, tenho certeza disso: pelo teu porte, pela tua inteligência, pela tua beleza. Mas a deusa que reprime o excesso dos prazeres? Não creio. Tua recordação só me inunda de alegria e suavidade", escreve em $1923 .{ }^{54}$ Por vezes, é possível perceber, pelas respostas de Mário, que Anita reagiu com veemência às investidas do amigo, quando este procurava orientar seus passos em Paris. Em mais de uma ocasião ele se queixa, por exemplo, do silêncio prolongado de Anita, e pede-lhe que mande notícias detalhadas de sua carreira. Em outros momentos, procura dissipar qualquer mal estar provocado por suas observações anteriores. Recorrentemente, seu propósito parece ser o de encorajar alguém que ainda não (re)encontrara seu caminho. Em abril de 1926, ele se mostra radiante por saber que sua participação no Salão dos Independentes chamara a atenção da crítica francesa e que uma de suas obras fora reproduzida em um artigo dedicado ao Salão. ${ }^{55}$ Escreve-lhe então, revelando uma vez mais suas expectativas em relação a seu trabalho:

Ah! Anita, enfim encontro de novo a minha Anita estupenda! Dei pulos pulões pulinhos de entusiasmo. Gostei mesmo e gostei muito e sobretudo gostei porque encontrei de novo a minha Anita a Anita do Japonês, da Estudanta Russa, do AutoRetrato e do Homem Amarelo, aquela Anita forte e expressiva, com uma bruta propensão pro desenho expressionista. Esta sim, esta é a querida minha Anita amada por quem bato armas faz tanto e com tanta confiança e gosto! $!^{56}$

O fato de ver a obra da amiga comentada no exterior talvez o tenha motivado a escrever um longo artigo a seu respeito em julho de 1926. Nele, após declarar não conhecer "alma carecendo mais de ser compreendida amada e louvada que a dessa sensitiva do Brasil" e explicar o retrocesso temporário de sua obra em função das críticas que recebera em 1917, afirma que ela "achara de novo a mão perdida e principia depois do turtuveio longo e tão dramático um período novo de criação". ${ }^{57}$

Todavia, logo em seguida, comenta em carta a Prudente de Morais Neto que escrevera

um artigo de anúncio sobre a coitada da Anita que está penando na Europa e toda a gente fala que completamente estragada. Pelas reproduções que vi em revistas francesas e fiz reproduzir aqui não me parece que esteja completamente estragada não porém essa é a opinião geral. E isso me entristece 
que você não imagina. (...) Anita quero muito bem e imagino que será terrível si quando ela chegar eu tiver a mesma opinião que toda a gente. Não sei si terei coragem de dizer pra ela não. ${ }^{58}$

Anita retorna definitivamente ao Brasil em setembro de 1928 e encontra o país mais afeito à causa moderna, embora preponderasse a posição nacionalista sobre a internacionalista. Tem como um de seus objetivos, ligado aos requisitos da bolsa, organizar uma mostra individual de sua produção mais recente. Assim o faz em fevereiro de 1929, expondo 56 óleos e 15 aquarelas na rua Liberó Badaró, em São Paulo. Mário de Andrade, porém, decepciona-se com a "variedade estética desnorteante" dos trabalhos então apresentados e escreve, em artigo no Diário Nacional:

Aprendeu também muito. Mas o progresso dela foi bem curioso... Não se pode falar que ela milhorou porque antes de partir Anita Malfatti já era uma grande pintora. Mas ganhou em amplitude, em variedade, o que não podia ganhar mais em grandeza pessoal. Talvez mesmo se possa dizer que perdeu alguma coisa... (...). Anita Malfatti pra adquirir a variedade estética até desnorteanete que apresenta na exposição de agora, careceu de sacrificar a grande força expressiva que tinha dantes..$^{59}$

Também Tarsila expõe no Brasil no ano de 1929, primeiramente no Rio de Janeiro, no Palace Hotel, e em seguida em São Paulo, na rua Barão de Itapetininga. Ressalte-se que essa foi sua primeira individual no país, e vinha acompanhada de um "acalentado catálogo" preparado por Geraldo Ferraz com textos de críticas parisienses das mostras ali realizadas. Conforme observa Aracy Amaral, para Tarsila essa exposição "é uma aguardada apresentação total, no Brasil, de seu rendimento como artista já apreciada em Paris". ${ }^{60}$

Sobre esta exposição comenta Oswald, ressaltando o papel de destaque de Tarsila no cenário artístico nacional:

O Rio de Janeiro vai descobrir Tarsila e vai ter com essa descoberta a exata sensação de um maravilhoso encantamento. Tarsila é o maior pintor brasileiro. Nenhum, antes dela, atingiu aquela força plástica (...) que ela só possui, entre nós. ${ }^{61}$

\section{O RECUO DE ANITA E O CONFRONTO COM TARSILA}

Não foram só os modernistas de primeira hora que rejeitaram as obras de Anita posteriores a 1917/1918, julgando-as significativamente inferiores a seu trabalho inicial, de viés expressionista. Vários estudiosos do movimento moder- 
nista brasileiro consideraram que a fase mais significativa de sua carreira encerrou-se com sua exposição histórica, a qual foi seguida por um marcado recuo formal que só se acentuou com o tempo. Para muitos, tal fato deveu-se, essencialmente, ao mal-estar causado na artista pelas ácidas críticas de Monteiro Lobato e pela conseqüente pressão exercida por sua família. Aracy Amaral, por exemplo, afirma que "sua pintura (...) se debilitaria sensivelmente a partir das críticas de Lobato e artista [perderia] sua vitalidade nervosa de 1917". ${ }^{62}$ Também Marta Rossetti Batista, autora do mais completo estudo publicado a respeito de Anita Malfatti, considera que "as mãos expressionistas começaram a duvidar da própria validade do caminho seguido, das conquistas alemães às norte-americanas" após a publicação do texto de Lobato. ${ }^{63}$ "Intimidada frente a críticas e pressões, a pintora recuou e perdeu importância", declara. ${ }^{64}$ Relembremos que em seu célebre artigo o escritor atacara duramente a "arte moderna", comparando-a à arte dos manicômios e afirmando que "os artistas que vêem anormalmente a natureza, e interpretam-na à luz de teorias efêmeras, sob a sugestão estrábica de escolas rebeldes (...) são produtos do cansaço e do sadismo de todos os períodos de decadência: são frutos de fins de estação, bichados ao nascedouro". ${ }^{65}$ Sobre Anita, Lobato assinalara "acentuadíssimas tendências para uma atitude estética forçada no sentido das extravagâncias de Picasso e companhia", embora ressaltasse seu "formoso talento":

Essa artista possui um talento vigoroso, fora do comum. Poucas vezes através de uma obra torcida para má direção, se notam tantas e tão preciosas qualidades latentes. (...) Entretanto, seduzida pelas teorias do que ela chama arte moderna, penetrou nos domínios dum impressionismo discutabilíssimo, põe todo o seu talento a serviço duma nova espécie de caricatura. ${ }^{66}$

Lobato conclui seu artigo afirmando que atuara enquanto um verdadeiro amigo da artista, pois evitara servir-se de "adjetivos bombons que a crítica açucarada tem sempre à mão em se tratando de moça". Ao contrário, julgara Anita "merecedora da alta homenagem que é tomar a sério o seu talento, dando a respeito da sua arte uma opinião sinceríssima, e valiosa pelo fato de ser o reflexo da opinião do público sensato, dos críticos, dos amadores, dos artistas seus colegas e... dos seus apologistas" ${ }^{67}$ Seu texto é irônico, mordaz. Se ele está repleto de críticas infundadas e observações estapafúrdias a respeito da "arte moderna", ele tampouco deixa de atacar a artista, considerando suas filiações equivocadas. Todavia, teria sido Lobato o único responsável pelo "declínio" da obra de Anita? Na opinião de Tadeu Chiarelli, não. Em Um Jeca nos vernissages, livro publicado em 1995, Chiarelli buscou repensar a célebre polêmica instaurada em 1917 e 
o recuo de Anita a partir de um ângulo menos comprometido com "uma história ideal do modernismo brasileiro". Em sua opinião, o texto de Lobato, "quando muito, pode ter acelerado na artista o processo de recuperação de uma pintura mais convencional, mais sensível à captação do ambiente circundante e mais presa aos aspectos tradicionais do 'bem pintar"'. ${ }^{68}$ A seu ver, já em agosto de 1916, quando Anita retornou a São Paulo, era possível perceber "uma significativa mudança em seu direcionamento":

Se até então sua produção se caracterizava não apenas pela expressividade, mas sobretudo por um perfeito entendimento da autonomia da pintura em relação ao assunto retratado, de volta ao Brasil nota-se que passa a dar destaque ao tema de suas pinturas, um destaque aliado a um tratamento menos intenso e mais convencional do plano pictórico. ${ }^{69}$

Outros historiadores, porém, sem rejeitar por completo o peso da palavra de Lobato, deram outra interpretação, também de cunho pessoal, para o progressivo distanciamento de Anita em relação às formulações mais radicais das vanguardas. Refiro-me à idéia de que a entrada em cena da bela e aristocrática Tarsila acentuou a insegurança pessoal de Anita, levando-a a retrair-se em seu trabalho.

Gilda de Mello e Souza, em texto sobre o movimento modernista, datado de $1975,{ }^{70}$ foi talvez uma das primeiras assinalar esse "confronto" entre duas mulheres de "trunfos tão desiguais", ${ }^{71}$ ressaltando o quanto deve ter sido difícil para "a moça feia e sem afeto amoroso" que foi Anita o convívio diário com a beleza e segurança de Tarsila. Segundo a autora, até aquele momento, a historiografia sobre o modernismo brasileiro canalizara para o artigo "tristemente célebre de Monteiro Lobato toda a responsabilidade do insucesso posterior da pintora [Anita]". A seu ver, os fatos foram mais complexos e deveriam ser revistos. Naquele momento de luta, afirma Gilda, Anita não se sentiu sozinha pois teve o apoio dos "ainda embrionários modernistas". Mais sérias, acredita, foram as outras provas, que a artista precisou enfrentar só. A primeira, assinala, foi o "evidente desacordo entre o seu temperamento e o nacionalismo, a que haviam aderido os companheiros". Que sentido, pergunta Gilda, "poderia ter isso para o seu temperamento fechado e solitário, que só contava com a arte para se exprimir? Como conter num programa estrito e definido a sua alma ferida, esquiva e no entanto sequiosa de comunicação?"72 A segunda prova, alerta a autora, foi a "dificuldade mais sofrida, porque Anita não a pôde confessar nem a si mesma":

Até agora ninguém a mencionou, porque, como os demais setores da cultura, a crítica reflete a visão masculina e estabelece de antemão a importância dos motivos esquecendo na 
sombra os que reputa insignificantes. No entanto, não é difícil avaliar o que terá sido para Anita o confronto diário com a beleza de Tarsila. É falso racionalizar, dizendo que era uma artista de prestígio e lhe bastava a admiração que os modernistas votavam à sua arte. Acaso manifestavam a Tarsila um interesse estritamente artístico? Não a consideravam também, além de excelente pintora, a 'maravilha caída do céu', a 'caipirinha vestida de Poiret', 'deusa', 'senhora do equilíbrio e da medida, inimiga dos excessos'? ${ }^{73}$

Gilda de Mello e Souza considera Anita "uma pintora de dotes excepcionais, que se expressava com igual segurança e senso dramático nos desenhos e nos óleos". Já Tarsila, a seu ver, foi uma "pintora de enorme talento, mas nem muito profunda nem excepcionalmente original". Em sua opinião, Tarsila tinha "algo da mentalidade de aluna; brilhante disciplinada, cumpridora de tarefas, imaginosa, mas que só inventa sobre um esquema preexistente. A sua sorte", afirma, "foi encontrar no caminho as normas de uma estética precisa e as linhas gerais de uma visão do mundo, às quais se acomodou com a docilidade de intérprete, de executante". Entretanto, Gilda não deixa de assinalar outro fator de relevo para seu desempenho estético: "o fato de ter sido uma mulher bonita (...) colaborou na expansão harmoniosa de sua personalidade. Se isto jamais interferiu diretamente na avaliação que os contemporâneos fizeram do seu talento, auxilou-a sem dúvida a cumprir seu destino". ${ }^{74}$ Quanto a Anita, "seu comportamento [em termos de retrocesso artístico] é o de quem foi rejeitada: pela vida, que não a fez bonita; pela crítica, que investiu contra sua arte; pela estética vigente, que não lhe permitiu extravasar o drama pessoal; pelos companheiros, que não a trataram como mulher". ${ }^{75}$

Em Nacional Estrangeiro, livro no qual analisa a rede de relações entre artistas modernistas e mecenato paulista, lançado em 2003, Sérgio Miceli retoma a idéia desenvolvida por Gilda de Mello e Souza, salientando a necessidade sentida por Tarsila, nos idos de 1923, de "fazer frente à dianteira técnico-estética da concorrente Anita Malfatti”:

A Tarsila que retorna à Europa em 1923, em companhia da filha adolescente, apaixonada por Oswald, é uma mulher atraente, sofisticada, repaginada com toaletes de alta-costura, decidida a alterar os rumos de seu aprendizado artístico, dando agora preferência a mestres ligados às vanguardas. (...) Tarsila, a desafiante, tanto em matéria artística como em termos de sedução pessoal, com a beleza esfuziante nos seus 36 anos, originária de riquíssima família da artistocracia rural (...), estava decidida a mobilizar o que fosse preciso para afirmar sua condição de mulher e artista bem-sucedida. ${ }^{76}$ 
Anita e Tarsila

Já Anita, "a profissional mais experiente e mais jovem, (...) possuía nas mãos o instrumento de sua redenção pessoal, social e o estigma responsável pelo bloqueio de uma vida amorosa". ${ }^{77}$ Miceli refere-se aqui ao defeito congênito na mão direita da artista, defeito esse insistentemente mencionado por todos os estudiosos de sua obra, os quais chegam a relacioná-lo ao fato de vários retratos da fase 'revolucionária' da artista apresentarem mãos cortadas e/ou parcialmente escondidadas. A mão deformada, sempre recoberta por um "lenço colorido displicentemente ali esquecido", transforma-se então em uma "fragilidade física", que, por sua vez, resultou em uma "fragilidade emocional", também recorrentemente citada. Segundo Miceli, tal fragilidade físico-emocional determinou a escolha profissional de Anita, assim como os rumos de seu trabalho, impedindo-a de traçar um percurso uniforme e sem vacilações:

Talvez as mesmas raízes e motivações que instigaram sua vontade de ser artista foram também responsáveis pela crise de identidade profissional que a fez retroagir em sua prática artística. A marca autoral de Anita tem a ver, sobretudo, com suas dificuldades de assumir sua plenitude afetiva como mulher, em parte por conta de suas constrições de imigrante, que a condenam ao celibato, em parte por força da postura defensiva que se viu impelida a adotar em virtude da mão defeituo$\mathrm{sa}^{.78}$

Para o autor, o confronto entre as artistas citadas estabeleceu-se, portanto, em bases bastante desiguais e a 'vencedora' não poderia ser outra:

Enquanto a estigmatizada Anita Malfatti constrói sua obra como protocolo sofrido de um itinerário afetivo marcado pela solidão e pelo isolamento, acossada por carências físicas e afetivas (a mão defeituosa, o celibato), a belíssima Tarsila do Amaral desenvolve o período de maior criatividade de sua carreira como artista plástica nos ritmos e conteúdos ditados pela parceria amorosa com o escritor Oswald de Andrade. ${ }^{79}$

Miceli entende que "o fato de algumas das mais importantes figuras do modernismo artístico brasileiro terem sido mulheres tornou as vivências ligadas à identidade sexual e de gênero um dos eixos temáticos e conceituais das formalizações expressivas da prática artística naquela geração". ${ }^{80}$

Mas estaríamos nós, mulheres, fadadas, por questões de gênero, a rivalidades em tais termos e a misturar o campo pessoal e o profissional de forma tão emotiva? Dito de outro modo, poderíamos utilizar esses mesmos parâmetros de análise para estudar a obra de pintores representativos de nosso movimento modernista? Estabelecer, por exemplo, um confronto entre o "filho e neto de modestos imigrantes italianos recém-instalados no interior paulista, coxo e de pequena 
estatura" $"$ que foi Portinari e o boêmio Di Cavalcanti, confronto esse que explicasse suas idas e vindas no campo artístico? Ou ainda entre o disciplinado e recatado Mário de Andrade e o irreverente Oswald? Não se trata de negar o encantamento de Mário de Andrade, Sérgio Millet, Menotti del Picchia, para não citar Oswald, em relação a Tarsila, tão evidente nos comentários citados anteriormente. Entretanto, cabe ressaltar que esta "sensitiva exaltada, mixto de adulto e de criança, independência e medo" ${ }^{82}$ que foi Anita soube procurar seu caminho, na França, de forma profundamente independente, sem acatar interferências ou sugestões. Enfrentou as críticas de Mário de Andrade e rejeitou bravamente suas orientações. Tampouco sucumbiu aos encantos de Tarsila ou permaneceu à sua sombra. Percebe-se, ao cotejar as trajetórias das duas artistas na Europa dos anos 1920, que cada uma buscou inserir-se no meio artístico parisiense a seu modo, valendo-se dos recursos (desiguais, de fato) de que dispunham. Ressaltese ainda que a crescente afinidade de Tarsila com o ideário do modernismo brasileiro é em muito tributária de sua relação afetiva com Oswald. Suas obras das chamadas fases pau-brasil e antropofágica têm um caráter pragmático bastante marcado. Nos dizeres de Ronaldo Brito, "Tarsila usava os esquemas cubistas para "pintar o Brasil", projetá-lo num espaço ideal até certo ponto tradicional", correspondendo assim às expectativas dos modernistas. ${ }^{83}$

Em várias ocasiões, Tadeu Chiarelli, sem entrar na questão de um possível confronto estabelecido entre Anita e Tarsila, buscou desmistificar a suposta "fraqueza emocional de Anita" como causa de seu "retrocesso" no campo das artes. Pare ele, trata-se, na verdade, de uma "atitude comum a outros artistas internacionais igualmente ligados às vanguardas como Picasso, Derain, Sironi e outros". Anita, a seu ver, sofreu do descaso que a história da arte oficial do século XX tratou "os artistas que, apenas circunstancialmente, tangenciaram o projeto moderno no decorrer de suas trajetórias e/ou que se engajaram por breve período nas correntes que contestavam tanto a tradição quanto a própria modernidade". ${ }^{84}$ Aos modernistas históricos e seus herdeiros não interessava

debater as razões estético-ideológicas que levaram Malfatti a abandonar as vanguardas após o período de militância em seus quadros (...). Para os modernistas, refletir sobre as razões que levaram a autora de Mulher de cabelos verdes a produzir telas mais convencionais (porém não menos interessantes do ponto de vista plástico), como $\mathrm{Nu}$ reclinado ou $\mathrm{A}$ japonesa, era tocar na contradição interna do próprio modernismo, debatendo-se entre as vanguardas e a volta à ordem. ${ }^{85}$

Em sua resenha sobre o estudo de Marta Rossetti Batista dedicado a Anita, Chiarelli elogia a tentativa da autora de "entender de fato o recuo da artista 
Anita e Tarsila

em relação aos postulados das vanguardas do início do século, em vez de julgar os passos posteriores de Malfatti, baseada em critérios da crítica moderna" e alerta para a necessidade de vermos "Anita Malfatti como protagonista de sua própria vida, optando conscientemente pelos rumos de sua trajetória artística, (...) e não como uma sensitiva influenciável, sem vontade própria, incapaz de arbritar sobre os caminhos de sua arte". ${ }^{86}$

Recebido em 02 de junho de 2008

\section{NOTAS}

${ }^{1}$ SIM IO N I, Ana Paula C avalcanti. "Eternamente amadoras: artistas brasileiras sob o o lhar da crítica". In: FABRIS, Annatereza (org.). Crítica e modernidade. São Paulo: ABCA e Imprensa O ficial. 2006, p. 152. 2 PESTAN A, N estor Rangel. "Anita Malfatti". O Estado de São Paulo. São Paulo, 29 nov. 1920. Apud BAT ISTA, Marta Rossetti. Anita Malfatti no tempo e no espaço. São Paulo: Edusp e Ed. 34, 2006, p. 259. Trata-se de artigo publicado por ocasião da exposição individual da artista, realizada em 1920. N ele, N estor Pestana define Anita como uma "talento sa pinto ra paulista" mas "por demais sensível às influências".

${ }^{3}$ AN DRADE, Mário. "O movimento modernista". In: . Aspectos da literatura brasileira. São Paulo: Livraria Martins Editora, 1974, p. 232 e 240.

${ }^{4}$ AN D RADE, O swald. "Aspectos da pintura através de Marco Zero". In: Ponta de lança, São Paulo: Ed. Globo, 1991, p. 125.

${ }^{5}$ AN D RADE, O swald de. "A exposição de Anita Malfatti". In: Jornal do Comércio, São Paulo, 11 jan. 1918. A pud BRITO, Mário da Silva. História do Modernismo Brasileiro: Antecedentes da Semana de Arte Moderna. Rio de Janeiro: C ivilização Brasileira, 1974, p. 55-56.

${ }^{6}$ Segundo relato tardio de Anita, Mário de Andrade, em uma de suas últimas visitas à exposição, entrega-Ihe um "cartãozinho": "- So u o poeta Mário Sobral, vim despedir-me. Vou sair de São Paulo. Então muito sério e cerimoniosamente ofereceu-me um soneto parnasiano sobre a tela 0 homem amarelo e acrescentou: - Estou impressionado com este quadro, que já é meu, mas um dia virei buscáIo". MALFATTI, Anita. "A chegada da arte moderna no Brasil". In: Conferências de 1951. São Paulo: Pinacoteca do Estado. 1951, p. 12. Apud BATISTA, Marta Rossetti. O p. C it, p. 220.0 escritor realizaria seu desejo em 1922, comprando o quadro na abertura da Semana de Arte Moderna de 1922.

${ }^{7}$ C onforme ressalta Marta Rossetti, Mário de Andrade refere-se aqui à terceira exposição individual de Anita no Brasil, realizada em 1920: "Mário de Andrade desconheceu sempre, em seus textos, a primeira individual, de 1924". In Idem, p. 272, nota 39.

${ }^{8}$ AN D RADE, Mário. "Anita M alfatti". Jornal dos D ebates, 5 out. 1921. Apud Ibidem, p. 270-76.

${ }^{9}$ HÉLIO S. "U ma palestra de arte". Correio Paulistano. São Paulo, 19 nov. 1920. Apud Ibidem, p. 25658.

${ }^{10}$ Anita M alfatti era o riunda de uma família de imigrantes qualificados. Seu pai, Samuel Malfatti era originário de Lucca, na Itália, e fixara-se em Campinas nos anos 1880, vindo ali a falecer em 1901. Era engenheiro e trabalhava em estradas de ferro e na construção civil. Após sua morte, Anita, sua mãe e seus três irmãos foram morar na casa dos avós paternos, de origem alemã. Em 1907 falece 0 avô, G uilherme Krug, e sua mãe vê-se obrigada a dar aulas de pintura e línguas para ajudar no sustento da família. 
${ }^{11}$ Tarsila do Amaral separa-se de seu primeiro marido, primo de sua mãe, pouco tempo após seu casamento, em 1904. Já havia estudado na Europa, em colégio interno, e propiciará a sua filha D ulce o mesmo tipo de formação. Contava com o total apoio da família, membros da "aristocracia rural provinciana", nos dizeres de Aracy Amaral, e até o final dos anos 1920 não lhe faltariam recursos materiais.

12 BATISTA, Marta Rossetti. O p. Cit, p. 236. A esse respeito, observa ainda Marta Rossetti às páginas 239-40: "Tem-se a impressão que a voz de Lo bato - se já não o fora começava a ser ouvida na casa dos Krug Malfatti. Pois, logo que Anita fechou sua exposição, em plena época da guerra e de exaltação nacionalista, Monteiro Lobato interessava-se por Alexandrino. (... ) N ão se sabe quanto tempo a pintora estudou com ele, e como reagiria à sua disciplina, bastante rígida. 0 certo é que em 1919 freqüentava o mestre das naturezas-mortas".

${ }^{13}$ Carta datada de 26 out. 1920. Apud AM ARAL, Aracy. Tarsila. Sua obra e seu tempo. São Paulo: Edusp e Ed. 34, 2003, p. 48-52

${ }^{14}$ C arta datada de 14 set. 1921. Apud BATISTA, Marta Rossetti. O p. Cit,, p. 268-69.

${ }^{15}$ D EL PICCH IA, M enotti. "Tarsila", A Gazeta, 27 dez. 1950. Apud AMARAL, Aracy. O p. Cit., p. 66. ${ }^{16}$ D epoimento de Menotti del Picchia a Aracy Amaral, 12 jan. 1968. In: Idem, p. 77.

${ }^{17}$ AMARAL, Tarsila. "Confissão geral". In: Exposição Tarsila 1918-1950. São Paulo, Museu de Arte Moderna, dez. 1950. Apud BATISTA, Marta Rossetti. O p. Cit, p. 293.

${ }^{18}$ Apud AMARAL, Aracy. O p. Cit., p. 74.

${ }^{19}$ Apud Idem, p. 72.

${ }^{20}$ AM ARAL, Tarsila. "C o nfissão geral". O p. Cit. Apud BATISTA, Marta Rossetti. O p. Cit, p. 294.

21 "D ata de setembro de 1922 a primeira correspondência que encontramos de 0 swald e Tarsila, ambos em São Paulo, época em que se iniciou o romance, correspondência que seria caracterizada por inúmeras viagens". In: AMARAL, Aracy. O p. Cit., p. 95. N o início de 1923, 0 swald já se encontra na Europa, viajando com Tarsila por Portugal e Espanha. $N$ as cartas que escreve à sua família, Tarsila não menciona o nome de 0 swald, com quem se casaria em 1926, após obter a anulação de seu primeiro matrimônio.

${ }^{22}$ Carta datada de 10 abr. 1923. Apud Idem, p. 98.

${ }^{23} \mathrm{C}$ arta datada de 23 mai. 1923. In: AM ARAL, Aracy (org.). Correspondência Mário de Andrade \& Tarsila do Amaral. São Paulo: Edusp/IEB, 1999, p. 57-8.

${ }^{24} \mathrm{~N}$ a carta em que fala so bre Léger, datada de 29 de setembro de 1923, Tarsila menciona seu desejo de estudar com Gleizes. Como vimos, meses antes, em carta a Mário de Andrade, ela já havia se referido a Gleizes como "seu mestre": "Hoje comecei com o Léger. Estive sábado passado no ateliê dele e levei alguns trabalhos dos meus últimos mais modernos. Ele me achou muito adiantada e gostou imensamente de alguns deles. Voltei para a casa animadíssima. Vou ver si tomo também umas lições com G leizes, artista avançadíssimo". A pud AM ARAL, Aracy. Tarsila. Sua obra e seu tempo, p. 119

${ }^{25}$ Apud Idem, p. 101-02.

${ }^{26}$ Apud Ibidem, p. 408

${ }^{27}$ Apud Ibidem, p. 419

${ }^{28}$ Em carta a Anita datada de $1^{0}$ de abril de 1939, Mário de Andrade pediria que ela se lembrasse "daquele amigo que o Freitas Vale chamou no salão dele, cheio de gente, para dizer em voz alta: 'Mário, aqui está o presente que lhe prometi: Anita conseguiu o prêmio de viagem'." In: BATISTA, Marta Rossetti (org.). Mário de Andrade. Cartas a Anita Malfatti (1921-1939). São Paulo: Forense U niversitária, 1989, p. 146.

${ }^{29}$ Apud BATISTA, Marta Rossetti. Anita Malfatti no tempo e no espaço, p. 298-99

${ }^{30}$ Em carta enviada a Yan de Almeida Prado em 11 de outubro de 1923, Sérgio Millet escreve que "a Anita está trabalhando infelizmente com o Maurício D enis". In: BATISTA, Marta Rossetti (org.). Mário de Andrade. Cartas a Anita Malfatti (1921-1939), p. 160, nota 24.

31 "A pintora Anita M alfatti regressou da Europa". O Jornal. Rio de Janeiro, 21 out. 1928. Apud BATISTA, Marta Rossetti. Anita Malfatti no tempo e no espaço, p. 319-20.

32 Idem. 
Caminhos e descaminhos do modernismo brasileiro: o 'confronto' entre

Anita e Tarsila

${ }^{33}$ Carta datada de 29 set. 1923. Apud AM ARAL, Aracy. Tarsila. Sua obra e seu tempo, p. 119. A exposição a qual se refere Tarsila acabou não ocorrendo. Ressalte-se que sua primeira exposição individual no Brasil apenas ocorreria em 1929.

${ }^{34}$ In: BAT ISTA, Marta Rossetti (org.). Mário de Andrade. Cartas a Anita M alfatti (1921-1939), p. 91-92.

${ }^{35}$ In: AM ARAL, Aracy (org.). Correspondência Mário de Andrade \& Tarsila do Amaral, p. 97-98.

${ }^{36}$ AM ARAL, Aracy. Artes plásticas na Semana de 22. São Paulo: Editora 34, 1998, p. 24.

${ }^{37}$ MICELI, Sérgio. N acional Estrangeiro. São Paulo: Companhia das Letras, 2003, p. 129.

${ }^{38}$ AMARAL, Aracy. Tarsila. Sua obra e seu tempo, p. 115. Em diversas cartas a Tarsila, 0 swald the recomendaria visitar Poiret e Patou, do is de seus costureiros de preferência, e cuidar muito de sua aparência. Para se ter uma idéia da preocupação de Tarsila com sua aparência, reproduzo uma das observações de Aracy Amaral sobre seus vestidos, contida na p. 10 do livro citado: "Em nota fiscal de Poiret, por exemplo, pode-se constatar que vários vestidos de Tarsila foram adquiridos do famoso estilista por 5 mil fancos cada, mesmo valor que D. O lívia G uedes Penteado pagou a Léonce Rosenberg por uma pintura de Léger, hoje no MASP".

${ }^{39}$ Apud Idem, p. 408

${ }^{40}$ Apud Ibidem, p. 185

${ }^{41}$ Ibidem, p. 11.

${ }^{42}$ BAT ISTA, Marta Rossetti. Anita Malfatti no tempo e no espaço, p. 299. N o caso de Anita, ela realizará uma cópia de Mulheres de Argélia, de Delacroix, e outra de Les Glaneuses, de Millet.

${ }^{43}$ Um artigo publicado em 1927, quando da participação de Anita no Salão dos Independentes afirmaria: "Anita M alfatti ama as cores e sabe se servir delas. E às vezes, co mo nesta $D$ olly, go sta de fazêlas reverberar e as opor umas às outras, e às vezes, ela estuda as nuances, como nestes limões escapando de um cesto de vime, sinfonia em amarelo que realça discretamente o rosa de uma tulipa aberta". PASC AL-LÉVIS. "Anita Malfatti". Les Artistes d'Aujourd'hui. Paris, fev. 1927. Apud Idem, p. 348. ${ }^{44}$ Apud Ibidem, p. 321.

45 In: BATISTA, Marta Rossetti (org.). Mário de Andrade. Cartas a Anita Malfatti (1921-1939), p. 120.

${ }^{46}$ Apud AM ARAL, Aracy. Tarsila. Sua obra e seu tempo, p. 112, nota 32.

${ }^{47}$ Idem, p. 112. E em 1962, ele assim se referiria a Tarsila: A to dos encantava, não só pelo talento como pela beleza. Porque era uma das mulheres mais bonitas de Paris, essa 'caipirinha' de Monte Serrat. Lembro-me de certa no ite em que, no Ballet des Champs Elysées, to da a platéia se voltou para vê-la entrar em seu camarote, com a negra cabeleira lisa descobrindo e valorizado o rosto e os brincos extravagantes quase to cando-Ihe os ombros suavemente amorenados". Apud Ibidem, p. 100.

${ }^{48}$ In: BATISTA, Marta Rossetti (org.). Mário de Andrade. Cartas a Anita Malfatti (1921-1939), p. 176.

49 Idem, p. 97-98. Carta datada de 19 mar. 1925.

50 lbidem, p. 88

${ }^{51}$ In: BATISTA, Marta Rossetti (org.). Mário de Andrade. Cartas a Anita Malfatti (1921-1939), p. 66.

Carta datada de 3 jan. 1924.

52 Idem, p. 103-04. Carta datada de 4 out. 1925.

53 Ibidem.

${ }^{54}$ In: AM ARAL, Aracy (org.). Correspondência Mário de Andrade \& Tarsila do Amaral, p. 57-58. Carta datada de 11 jan. 1923.

55 Trata-se do artigo de André Warnod, "Au Salon des Indépendants", publicado in Comoedia, Paris, 28 mar. 1926

${ }^{56}$ In: BATISTA, Marta Rossetti (org.). Mário de Andrade. Cartas a Anita Malfatti (1921-1939), p. 116.

${ }^{57}$ Apud BATISTA, Marta Rossetti. Anita Malfatti no tempo e no espaço, p. 245 e 339.

${ }^{58}$ In: BATISTA, Marta Rossetti (org.). Mário de Andrade. Cartas a Anita Malfatti (1921-1939), p. 187. Carta datada de 28 jul. 1926.

${ }^{59}$ AN D RADE, Mário. "Anita M alfatti". D iário N acional. São Paulo, 5 mar. 1929. Apud BATISTA, Marta Rossetti. Anita Malfatti no tempo e no espaço, p. 367. Em 1931, Mário comenta a participação da amiga no Salão N acional de Belas Artes, conhecido como "Salão Revolucionário" em termos depreciativos: "O que Anita faz de novo me inquieta". A inquietação transforma-se em seguida em "franca desapro- 
vação" dos rumos tomados pela pintora, conforme salienta Marta Rosetti Batista in Mário de Andrade. Cartas a Anita Malfatti (1921-1939), p. 35.

${ }^{60}$ AM ARAL, Aracy. Tarsila. Sua obra e seu tempo, p. 309.

${ }^{61}$ Idem, p. 314. U ma comitiva de amigos da artista partiu de São Paulo para visitar a exposição de Tarsila no Rio de Janeiro. Curiosamente, fazia parte desta comitiva Patrícia Galvão, a Pagu, que viria a ser a próxima companheira de 0 swald de Andrade.

${ }^{62}$ AM ARAL, Aracy. Artes plásticas na Semana de 22, p. 250.

${ }^{63}$ BATISTA, Marta Rossetti. Anita Malfatti no tempo e no espaço, p. 238.

${ }^{64}$ Idem, p. 18

${ }^{65}$ LO BATO M M nteiro, "Paranóia e Mistificação". O Estado de São Paulo. São Paulo, 20 dez. 1917. Apud BRITO, Mário da Silva. O p. Cit., p. 46-50.

${ }^{66}$ Idem.

${ }^{67}$ Ibidem.

${ }^{68}$ C HIARELLI, Tadeu. U m Jeca nos Vernissages. São Paulo: Edusp, 1995, p. 24.

${ }^{69}$ Idem, p. 21.

70 Trata-se de "Vanguarda e N acionalismo na década de Vinte", originalmente escrito para figurar no catálogo da exposição 0 modernismo - pintura brasileira contemporânea de 1917 a 1930, realizada no Museu Lasar Segall. 0 texto foi reproduzido in: MELLO E SO UZA, Gilda. $O$ Baile das $Q$ uatro Artes. Exercicios de Leitura. São Paulo: Livraria D uas C idades, 1980, p. 249-77, versão na qual me baseio para as citações.

${ }^{71}$ A expressão é de Sérgio Miceli, em livro que analisaremos em seguida.

72 MELLO E SO UZA, Gilda. Op. Cit., p. 271.

73 Idem, p. 271-72.

74 Ibidem, p. 269

75 Ibidem, p. 272.

${ }^{76}$ MIC ELI, Sérgio. O p. C it., em especial os capítulos "Anita Malfatti: gênero e experiência imigrante" e "Tarsila do Amaral: a substituição de importações estéticas". A citação encontra-se nas páginas 115 e 130.

77 Idem, p. 115.

78 Ibidem, p. 123.

${ }^{79} \mathrm{Ibidem}$, p. 97. Em seu texto, Miceli refere-se ainda ao amor platônico de Anita em relação a seu amigo Mário, e analisa alguns de seus quadros dentro desse prisma.

80 Ibidem, p. 102.

${ }^{81}$ Sérgio Miceli assim se refere a Portinari em seu livro Imagens $N$ egociadas. Retratos da elite brasileira (1920-1940). São Paulo: Companhia das Letras, 1996.

${ }^{82}$ As expressões são de autoria de M arta Rossetti Batista.

${ }^{83}$ BRIT O, Ronaldo. "O trauma do Moderno". In: Arte Brasileira Contemporânea. Cadernos de Texto 3. Sete ensaio s so bre o Modernismo. Rio de Janeiro: Funarte, 1983, p. 19.

${ }^{84}$ C H IARELLI, Tadeu. "Anita Malfatti no tempo e no espaço". In: Arte internacional brasileira. São Paulo: Lemos editorial, 1999, p. 158.

${ }^{85}$ CH IARELLI, Tadeu. "Äs margens do modernismo". In: AG U ILAR, N elson (org.), Bienal Brasil século XX. São Paulo: Fundação Bienal, 1994, p. 86.

${ }^{86}$ CHIARELLI, Tadeu. "Anita Malfatti no tempo e no espaço", p. 162. 